\title{
Local Government and Fiscal Autonomy for Local Government In Nigeria
}

\author{
Eme, Okechukwu I. \& Izueke, Edwin \\ Department of public administration and local government \\ Email: okechukwunncnt@yahoo.com \\ Ngozi Ewuim, PhD \\ Department of Public Administration \\ Nnamdi Azikiwe University, Awka
}

\begin{abstract}
Local autonomy is a term that is frequently employed in both academic and popular discussions of local government, but it is rarely defined conceptually in a careful way or operationalised and subject to empirical research. In this paper we present a working definition of "local government autonomy" based on dimensions fundamental to the concept, identify variables to operationalize those dimensions, utilize factor analysis to combine those variables into underlying component factors. We also use the recent Presidential Bill sent to the National Assembly to support the need to abrogate the State-Joint Account. The paper also highlights, analyses and examines the factors that are responsible for lack of independence and fiscal autonomy by local government. The authors further assessed the extent of decentralization and inter-governmental relations in Nigeria impact on the Local Government. In conclusion, the authors pointed out that lack of independence of the local governments is as a result of lack of fiscal autonomy which in turn explains the duplicity of decentralization and inter-governmental relations in Nigeria.
\end{abstract}

Keywords: Local Autonomy, Decentralizations, Federalism, Intergovernmental Relations, \& State-Joint Account.

\section{Introduction}

Since the inception of the system of local government in Nigeria, there had been persistent clamour for the autonomy of the local government as the third tier of governance in the federation. It is interesting to note that even the federal government has in recent times joined in championing the course of local government autonomy. In the forward of the guidelines for the 1979 local government reforms, it was clearly remarked that, "the states have continued to encroach upon what would have been the exclusive preserve of local governments. With this reform, the local government was granted the power of grassroots governance with apparent improvement in the autonomy as the third tier of government in the country.

In order to strengthen the autonomy and philosophy of government at the local level, The Federal government guaranteed the statutory nature of local government by embodying it in the 1979 constitution. In section 7(1) of the constitution, it was stated that, "the system of democratically elected local government councils is under this constitution guaranteed". Even the military administration of General Ibahim babangida from 1986 took bold steps to strengthen the autonomy of local government. By January 1988, good measures of autonomy came the way local government with the scrapping of the state ministries of local government throughout the 
country thus removing the political control and bureaucratic redtapism perpetuated by these state ministries. According to Adeyemo (2003) other efforts made towards strengthening local government autonomy include;

- The approved scheme of service for local government employees following the recommendation of the Oyeyipo Committee report of March 1988.

- The direct disbursement of funds to local governments; thus preventing the hijacking of the funds of local government by the state governments (through the federal pay offices).

- Subsequent increases in the statutory allocations to local government in the 1989 constitution which are aimed to remove the inadequacies of the local government system viz; section 7(8), section 292 and section 304 etc.

While admitting that local government autonomy cannot be absolute in a federation it is pertinent to note that local governments need to be granted good measure of fiscal autonomy so as to be able to carry out effectively the task of rural development.

These series of reforms carried out by the federal government in order to strengthen the local government as the third tier of government in the federation has given rise to visible improvements of the revenue base of the councils.

It has been stated earlier in the paper that the Act which established the state Joint Local Government Account (SJLGA) was passed in 1981 by the National Assembly but the eventual domestication and implementation of the provisions of the Act by the states in the federation only took effect in the early years of the fourth republic when state house of assembly passed the SJLGA laws to give effects to that constitutional provisions.

Studies conduced by this researcher in Enugu state for the period under review shows that the law establishing the joint account allocation committee was enacted in 2001. This law was published in Gazette No. 6 of 2001 under the caption "State Joint Local Government Account/Distribution of Revenues and other related matters law 2001.

It is good news that President Goodluck Jonathan has forwarded a Bill to the National Assembly to stop the operation of the joint state/local government accounts. The president's action is predicated on calls by well- meaning Nigeria for financial autonomy to be granted the constitutionally recognized 774 local government areas in the country.

The Minister of Culture and Tourism, Chief Edem Duke, who stated this in Abuja recently, also said that government is fully committed to ensuring that effective local government system that would serve as a catalyst for grassroots development is entrenched. The bill, if passed into law and assented to by the president would be one of the best that has emanated from presidency we are hopeful become law.

For many years, local government allocation has been hijacked by the various state governments because of absence of a truly local government system in our practice of democracy. Section 7 (1) of the 1999 constitution allows for an elected administration in the councils but in practice, most of the councils in Nigeria are administered b appointed chairmen or caretaker committees. Only very few can be said to be under democratically elected officials. Even in those with elected administrations, their finances are under direct control of the state government. Hence there is no visible development in practically all the 774 councils in Nigeria. Their roads are as dilapidated as ever. There is nothing to show that there is grassroots government in Nigeria. And, this is the tier of government that is supposed to be closer to the people. Unfortunately, they are not centres of exist only on paper. In reality, they are not centres of rural governance and development. 
Ordinarily, local government is supposed to be the third tier of government. As a third tier government, all local government are supposed to be independent. And, because some state governors do not ascribe to this independence, they have done all in their power to ensure the emasculation of the councils so that they can utilize their federal allocations they like. One instrument that gave the governors the power of control of the councils is the state/local government joint accounts. Once this umbilical cord is broken, the councils can be in a position to develop their areas.

Under the uniform account system, state have dictated projects for councils and disbursed council funds as they like. That is why officials at the local government level are largely not elected. In some states where elections were held in the councils, the party in power ensured that its candidates won all the seats. They do this in connivance with electoral officers of the state independent electoral commission (SIECs). This scenario obtains because SIEC officials are appointed by the governor, who expect them to loyal to him and his party. With SIEC in place, outcome of council polls are predictable. With SIEC it will be difficult for the opposition to win an election at council level. This is why many state governments have not conducted council polls despite constitutional provision for elected council administration in the country.

\section{Contextualisation of Local Government Fiscal Autonomy}

Local Government fiscal autonomy is derived from the fiscal federalism as is operated in the Nigerian federation. Fiscal federalism is the transfer of functions, resources and authority to peripheral levels of government. It also relates to the "disposition of tax powers," retention of revenue and methods adopted in sharing centrally collected revenue in accordance with the constitutional responsibilities of all levels of government (Osakwe, 1999:524).

In line with the current reforms, the defunct Centre for Democratic Studies (CDS) defines local government autonomy as, "the relative discretion which local government enjoy in the regulation of their own affairs". According to Tukur, fiscal federalism is all about fiscal equity and financial independence among the federating units. The extent to which local governments are free from the control of the state and federal government in the management of their local affairs" (Adeyemo, 2005).

While Nwabueze (1983) sees the autonomy under the federal system as each tier of government enjoying a separate existence and independence from the control of the other governments. It is an autonomy which requires not just the legal and physical existence of an apparatus of government like a legislative assembly, governor, court etc, but that each government must exist not as an appendage of another government but as autonomous entity in the sense of being able to exercise its own will in the conduct of its affairs free from direction of another government.

Local government autonomy can also be defined as "the freedom of the local government to recruit and manage its own staff, raise and manage its own finances, make bye-laws and policies, and discharge its functions as provided by law without interference from the higher governments (Ogunna, 1991:350, quoted in Okafor, 2010). This includes the political, financial and administrative autonomy. Financial autonomy of local government entails the "freedom to impose local taxation, generate revenue within its assigned sources, allocate its financial and material resources, determine and authorize its annual budgets without external interference" 
(Okafor, 2010), fiscal autonomy is therefore the bedrock and most important aspect of local government autonomy.

\section{Background to the State Joint Local Government Account}

The state Joint Local Government Account (SJLGA) was initially introduced in the Nigerian federation as far back as 1981 during the second Republic administration of president Shehu Shagari. Conscious of the fact that the Nigerian economy is a mono economy where over $80 \%$ of both the federal, state and local governments revenues come from their shares of the oil wealth, the administration ostensibly wanted to create a platform where both the federal and state governments could play some roles in funding and monitoring the local government revenue earnings and expenditure to ensure their success in rural development.

The joint account system was brought into being through an act of the national assembly known as "allocation of revenues (federation accounts etc) act 1981 (Daily Trust, July, 27, 2006). The same act established what is today known as Federation Account Allocation Committee (FAAC), currently chaired by one Chief Olukayode Anjorin. The committee holds meeting every month. However, during intervening military eras in Nigeria, decrees were enacted by the Federal Government such as decree 49 of 1989 which established for the Federation (note the word Federation, not Federal government), the Revenue Mobilization, Allocation and Fiscal Commission (RMAFC) with powers to "monitor the accruals and disbursement of revenue allocations from the federation account". This specific power of RMAFC amongst other functions in the above decree is sustained in section 153N sub-section 31 and 32 (a e) part 1 of the $3^{\text {rd }}$ schedule to the 1999 constitution (Daily Trust, 2006).

This decree 49 of 1989 which established RMAFC made the commission a member of the Federation Accounts Allocation Committee (FAAC) as well as the State Joint Account Allocation Committee (JAAC). However, while the State Joint Local Government account (SJLGA) is retained in the 1999 constitution, the Federation Account Allocation committee (FAAC) was omitted or in a lighter word, dropped.

The 1999 constitution of the federal republic of Nigeria also stipulated the legislative power over public funds, especially on SJLGA, in section 162, Sub-section 18. specifically, section 58 of the constitution states:

The amount standing to the credit of local government councils in the federation account shall also be allocated to the states for the benefits of their local government councils on such terms and in such manner as may be prescribed by the national assembly.

Each state shall maintain a specific account to be called "state joint local government account" to which shall be paid all allocations to the local government councils of the state from the federation account and from the government of the state.

Each state shall pay to the local government councils in its area of jurisdiction such proportion of its total revenue on such terms and in such manner as may be prescribed by the national assembly. 
The amount standing to the credit of local government councils of a state shall be distributed among the local government councils of the state on such terms and in such manner as may be prescribed by the house of assembly of the state.

But decree No 160 of 1992, sub-section 5(2) specifically stated that the $10 \%$ of each state's internally generated revenue payable to the local government councils in the state shall be distributed among the local government in the state on such terms and in such manner as the state house of assembly may prescribe.

Nevertheless, up till year 2000 when there was no joint account committees, local government councils picked up the cheques for their allocations from the federal pay offices (PPOS) in their respective states. These FPOS religiously kept records of all the allocations collected and the accountant General's office still publishes such remittances/disbursements to states and local governments for public consumption at regular intervals.

Those provisions introducing the joint account system since 1981 had remained silent and unimplemented by the states due to the constant interruptions of the military in the political process. However, on resumption of civilian democracy from May 1999, some interest groups with obvious ulterior motives for the allocations prevailed on the state chief executives who adopted the sections of the 1999 constitution dealing on the state joint local government account system and consequently set-up the joint account system in their respective states (This day July 21, 2006).

Since the inception of the system of local government in Nigeria, there had been persistent clamour for the autonomy of the local government as the third tier of governance in the federation. It is interesting to note that even the federal government have in recent times joined in championing the course of local government autonomy. In the forward of the guidelines for the 1979 local government reforms, it was clearly remarked that, "the states have continued to encroach upon what would have been the exclusive preserve of local governments. With this reform, the local government was granted the power of grassroots governance with apparent improvement in the autonomy as the third tier of government in the country.

In order to strengthen the autonomy and philosophy of government at the local level, The Federal government guaranteed the statutory nature of local government by embodying it in the 1979 constitution. In section 7(1) of the constitution, it was stated that, "the system of democratically elected local government councils is under this constitution guaranteed". Even the military administration of General Ibahim babangida from 1986 took bold steps to strengthen the autonomy of local government. By January 1988, good measures of autonomy came the way local government with the scrapping of the state ministries of local government throughout the country thus removing the political control and bureaucratic redtapism perpetuated by these state ministries. According to Adeyemo (2003) other efforts made towards strengthening local government autonomy include;

- The approved scheme of service for local government employees following the recommendation of the Oyeyipo Committee report of March 1988.

- The direct disbursement of funds to local governments; thus preventing the hijacking of the funds of local government by the state governments (through the federal pay offices).

- Subsequent increases in the statutory allocations to local government in the 1989 constitution which are aimed to remove the inadequacies of the local government system viz; section 7(8), section 292 and section 304 etc. 
While admitting that local government autonomy cannot be absolute in a federation it is pertinent to note that local governments need to be granted good measure of fiscal autonomy so as to be able to carry out effectively the task of rural development.

These series of reforms carried out by the federal government in order to strengthen the local government as the third tier of government in the federation has given rise to visible improvements of the revenue base of the councils.

It has been stated earlier in the paper that the Act which established the state Joint Local Government Account (SJLGA) was passed in 1981 by the National Assembly but the eventual domestication and implementation of the provisions of the Act by the states in the federation only took effect in the early years of the fourth republic when state house of assembly passed the SJLGA laws to give effects to that constitutional provisions.

Studies conduced by these researcher in Enugu state for the period under review shows that the law establishing the joint account allocation committee was enacted in 2001. This law was published in Gazette No. 6 of 2001 under the caption "State Joint Local Government Account/Distribution of Revenues and other related matters law 2001. The following provisions were made by the law;

Composition the Committee

1. (a) Chairman

(b) One Treasurer of a Local Government Council to be appointed by the Governor from each of the senatorial Zones of the state in rotation.

(c ) One member from each of the zones of the state who in the opinion of the Governor are persons of unquestionable integrity with requisite qualifications and experience.

(d) One representative of the ministry of finance and another of the office in charge of Local Government matters both of whom must not be below the rank of GI-13in the civil service of the state.

2. The committee shall liaise with the Accountant General of the state in the discharge of its function.

\section{Secretary:}

There shall be appointed by the Governor a Secretary of the committee who shall carry out duties as prescribed in this law and shall;

a. Issue notices of the meetings committee as directed by the chairman.

b. Performance such other functions as the committee or the chairman may from time to time direct.

Allocation of Revenues to the Local Government Councils by JAAC

The Act stated that, any amount which shall be set out by the committee at any time for distribution from the amount standing to the credit of Local Government Councils in the Joint Account shall be distributed among the local government councils by the Joint Account Allocation Committee (JAAC) in the following manner;
a. $40 \%$ on the basis of equality
b. $25 \%$ on the basis of population
c. $20 \%$ on the basis of primary school enrollment
d. $10 \%$ on the basis of internally generated revenue 
e. $5 \%$ on the basis of landmass.

\section{Some Deductions Provided for by the Law:}

The deductions provided for under the Joint Account Law tagged "First-Line-Charges" include the following;

- Local Government Education Authority gross salary

- Local Government Education Authority Overhead

- Total Education Fund payable

- Pension Fund allowance.

- Training fund

- Traditional rulers

\section{The Implications of the Joint Account System on Local Government Fiscal Autonomy}

The paper reveals the following;

a. The laws made by the State houses of Assembly to bring the State Joint Local government Account (SJLGA) into force are usually tilted to favour ends thereby compounding the already distressed financial positions of the councils.

b. The key officers of the Joint Account Committee set up by the State governor are state government representatives who function on the directive of the State Chief Executives with little or no control form the Council Chairmen who are the statutory owners of the fund as the chief accounting officers of their Local Governments.

c. Most of the Local Government councils were not even represented in the Joint Account Allocation Committee (JAAC).

d. The Council who are the chief accounting officers of their respective Local Governments were never briefed as to how much accrued to their councils monthly from the Federation Account before sharing.

e. Substantial amounts of the allocations from FAAC to each of the Local Government Councils were deducted at source in the name of Joint projects or any other contrived reasons.

f. The council chairmen who picked up the courage to protest over the unwarranted deductions from their councils' statutory allocation were threatened and some were even sacked from their positions for daring to query the activities of the joint Account Allocation Committee (JAAC) by the State Governors.

g. State governments that are constitutionally required to fund local government councils have instead used the SJLGA provisions to hold local governments hostage and make them mere appendages of the stat thereby practically denying the local government councils their financial autonomy (Okafor, 2010).

This study shows that the Revenue Allocations that accrued to Local Government Councils in the States were not only deducted at source but that they were in some occasions totally withheld by the State Government through the Joint Account Committee. 


\section{Recommendations}

We applaud the president for coming forth with this important bill that will restore financial autonomy to the councils. It is, indeed, a bold but necessary initiative that will instill confidence and give verve to the Local Government system in the country.

Let the National Assembly expedite action on the Bill and pass it so that the president can assent to it. But the new initiative should not, in any way, be an invitation for council chairmen to become emperors.

At the same time, urge the federal legislators to resist any attempt to kill the Bill. In fact, the legislators should ensure that the structure of the councils is clearly defined so that state governors would not encroach on their activities. Let them not succumb to pressure and lobbying from governors to stifle the Bill.

This Bill is of national interest and importance. Local government autonomy should not stop at finances; it should cover elections into the councils as well. Over time SIEC has not lived up to public expectation where conduct of council polls is concerned. In all its elections, the party in power in any state usually wins the entire seats. This is not good for our democracy.

Perhaps, the Independent National Electoral Commission (INEC) will in future handle council polls just as it handles all others polls in the country. All elected council officials should have uniform tenure throughout the country. We say this because SIECs, as experiences has shown, are more often than not loyal to the governments that appoint their members

\section{Conclusion}

The Nigerian federation is a three tier structure which saddles each level of government with responsibilities. It is saddening to note that these responsibilities are performed by mostly only transfers from federal government and to an extent by the states and thereby not allowing the local councils to enjoy the deserved political and administrative autonomy because there cannot be absolute autonomy without fiscal autonomy. In view of the above explanation whereby fiscal power is not decentralized but centralized and there is no fiscal autonomy enjoyed by local governments, the pattern of inter-governmental relations in Nigeria is not in tune with true federalism. The lacks of administrative independence and fiscal autonomy by local governments have exposed the duplicity of the so called decentralization and inter-governmental relations in Nigerian federalism. There is the need to review the vertical sharing formula such that it can reflect a decentralized fiscal system. Also to be reviewed and restructured is the fiscal dependency of the local governments on the federal and state governments. Finally, the government at all levels, particularly the local government must be ready to diversify and embark on policy reforms with respect to revenue generation and mobilization. The local governments should wield their powers and legal authority to impose taxes rather than to depend heavily on federal and state governments grants or allocations. 


\section{References}

Adeyemo, D.O. (2005), "Local Government Autonomy in Nigeria: A Historical Perspective" Available online@ @ttp://www.elgf.org.uk/index.cfm/pageid/112/Nigeria.

Carr J.B. (2005), Local Government Autonomy and State reliance on Special Districts Governments: A Reassessment, Political Research Quarterly Available online@jcarr!wayne.edu.

Enugu State Ministry of Finance (Official Records), "Distribution of Revenues to Local Government Councils" (May 1999, May 2007).

Enugu State Official Gazette No 6, 2007 'State Joint Local Government Account, Distribution of Revenues and other related matters Law, 2001.

Federal Ministry of Finance, "Revenue Allocations to States and Local Governments by the Federation Account Allocation Committee (FAAC) Available online@www.fmf.gov.ng-accessed on 3/3/10.

Osakwe, J.O. (1999), "Fiscal Relations among Three Tiers of Government in Nigeria" in Fiscal Federalism and Economic Development (NES), University Press.

Shuaib Y.A. (2002), "Local Government Financial Autonomy in Nigeria: "The State Joint Local Government Account, Common wealth Journal of Local Governance, July 2010 available online@ @ttp://express.lib.uts.edu.au/ojs/index.php/cjlg-accessed28/01/11.

Sylvanus, Nzuta Aaogwa; Inter-Government Relations: the Nigerian Experience: Immaculate Publication Limited; Enugu, 2009.

Godwin Onwusi; "Local Government Autonomy and the 1999 Constitution; A case for review", Presented at a workshop organized by Ebonyi State House of Assembly on the Amendment of the 1999 Constitution; November, 1999.

Tukur (2007), "Fiscal Federalism and the Taxonomy of Revenue Allocations, Mechanism, Conflicts and Coordinations" A presentation at the Nigerian Governors Forum Retreat, $26^{\text {th }}$ and $28^{\text {th }}$ October 2007, Abuja International Conference centre. 